\title{
DIPLOCAT's Public Diplomacy role and the perceptions towards Catalonia amongst international correspondents
}

\begin{abstract}
This qualitative study analyses the public diplomacy (PD) role of the Public Diplomacy Council of Catalonia (DIPLOCAT) and delves into the perceptions that international correspondents have towards this region.

The objective of DIPLOCAT is to influence foreign public opinion in relation to Catalonia's will of self-determination. This study proves that international correspondents who have established prior contact with DIPLOCAT in turn also have a positive perception of Catalonia. The research has also found a correlation between the professional needs of correspondents (information sources and materials) and the PD activities being provided by DIPLOCAT. This fact shows that correspondents' interests are in line with what DIPLOCAT is strategically offering. These achievements demonstrate that, within the new information age, a small PD structure such as DIPLOCAT is able to achieve remarkable profits in terms of reputation gaining for the territory it represents if the right tools and strategies are used.
\end{abstract}

Keywords: DIPLOCAT, public diplomacy, public opinion, Catalonia perception, international correspondents.

\section{Background}

The field of public diplomacy (PD) is probably one of the most multi-disciplinary areas in modern scholarship. Malone (1985) describes it as, "direct communication with 
foreign peoples, with the aim of affecting their thinking and, ultimately, that of their governments". This is done by following a two-step process: first, by creating supportive public opinion in another state, and second, by pressuring this public to force its government to adopt favourable policies towards the government employing PD (Gilboa, 2008). As Castells points out, in contrast to government diplomacy, the goal of public diplomacy is to project the values and ideas of the public to the international arena (Castells, 2008).

Indeed, the new era of interdependence in international relations has led to new models of exercising power. Soft power, for instance, expresses that the ability to establish preferences "tends to be associated with intangible assets such as an attractive personality, culture, political values and institutions, and policies that are seen as legitimate or having moral authority" (Nye, 2008). Soft power causes people to act through cooperation rather than coercion, inducements and payments, which would be hard power actions. Soft power, therefore, is not only merely influence, but also attractiveness in behavioural terms (Nye, 2008).

A country's soft power values are often transmitted through international media channels that countries work with in order to build and promote their reputation (Gilboa, 2008). This is why it is also important to consider the capacity that journalists have to influence their audiences' picture of the world (McCombs and Reynolds, 2002). Through their reports, foreign correspondents shape the image of a country in foreign audiences' eyes (Archetti, 2011) and sometimes "determine the national interest and usurp policy making from elected and appointed officials" (Gilboa, 2005, p.63).

The reputation of a country has a profound impact on its social, cultural, economic and political destiny due to individuals experiencing society through a range of perception (Anholt, 2007). Image and reputation help to achieve political and economical goals in 
the global arena and therefore can be seen to be invaluable national assets, instruments of power and a clear example of a nation's soft power (Leonard, 2002).

Public diplomacy main components were identified by Cull (2008) as being these: listening, advocacy, cultural diplomacy, exchange, and international broadcasting. All of them, though, are interconnected, and must be managed in a coherent, coordinated and synergetic way. As Cull (2010) explains, public diplomacy begins with listening to foreign citizens, must be connected to policy, must be committed to engage international publics rather than to impress domestic audiences and requires credibility as well as a collective undertaking.

Besides that, it could be argued that the creation and management of a country's image can be easier for smaller states, as the domestic stakeholders of larger countries are often less interconnected between themselves (Quelch and Jocz, 2004). In addition, "the political and business elites know each other and can more easily formulate a common policy" (Quelch and Jocz, 2004, p. 234), thus establishing a more coherent image internationally.

However, public diplomacy and the creation of national reputation are not tools and features solely employed by nation-states but also by sub-national institutions or cultural nations (Xifra, 2009). This is the case with Catalonia, a Spanish region that is not recognised as a nation, despite possessing the characteristics of one. Following Guibernau (2014) we understand nation as "a human group conscious of forming a community, sharing a common culture, attached to a clearly demarcated territory, having a common past and a common project for the future, and claiming the right to rule itself".

Not possessing a state of its own, Catalonia is often perceived as remaining in a position of inferiority due to the fact that it is not represented in international forums. 
Nevertheless, Catalonia can be understood as an example of stateless national building (Xifra and McKie, 2012; San Eugenio and Xifra, 2015) and has developed its European and international tradition over almost 25 years through belonging to Spain and to the EU (Badia, 2010). The most important cornerstone of this process was Catalonia's Foreign Action Plan 2010-2015, a project designed to make Catalonia a global actor through the use of public diplomacy strategies (San Eugenio and Xifra, 2015).

Though nationalistic claims can be traced back in all along the XXth century (Keating, 1996), and after a few years of Catalan society holding demonstrations and regional Parliament producing some majorities in favour of an independence referendum, Catalonia is now bringing the political debate to the international arena. As San Eugenio, Ginesta and Xifra (2017) point out: "Catalonia is faced with the challenge of persuading international public opinion that it should become a state in its own right".

To do so, two main tools have been deployed by the Catalan Government: the Eugeni Xammar Programme of International Communication and Public Relations and the Catalan Public Diplomacy Council (DIPLOCAT).

On the one hand, the Eugeni Xammar Programme, founded in 2012, aims at establishing a fluid and permanent channel of communication with international media though, in the last years, there has been little activity.

On the other hand, the Public Diplomacy Council of Catalonia (DIPLOCAT) is a consortium created in 2012 with the aim of co-ordinating and facilitating dialogue between around 30 public and private institutions, which makes up the consortium's body. DIPLOCAT has its own legal identity and it establishes relations with the Secretariat for Foreign Affairs and the European Union of the Catalan Government. In 2015, DIPLOCAT managed a budget of $€ 2,601,000$ and employed 13 people.

Through this public-private consortium, Catalonia is developing its own public 
diplomacy strategy, with the 'right to decide' as a central issue, and promoting relations with international actors taking advantage of the new- information age and parallel diplomacy, which is also known as paradiplomacy. This concept has broken the traditional practice of diplomacy, a type of practice followed by nation-states. Paradiplomacy takes into account relations at regional or non-state level (Xifra and McKie, 2012). Thus, Catalonia is utilising its institutional capacity by taking advantage of deregulation, liberalization and privatization of the rules and procedures used by nation-states in order to keep control over the activities within its borders (Castells, 2008). As Badia points out, regions, metropolitan areas and cities, "have already overcome the horizon traditionally established from the central power and have become the managers of their own future" (Badia, 2010, p. 22).

Considering that realpolitik, understood as the foreign pragmatic activity is limited to states, Catalonia's soft power and public diplomacy have taken profit of today's noopolitik age (Xifra and McKie, 2012). The "noopolitik" idea refers to a new strategic approach based on the noosphere, a concept that encompasses two notions of the new information age: the cyberspace and the infosphere. As Hayden points out (2013), information and communication technologies (ICTs) have been incorporated as a tool for carrying foreign policies strategically. Consequently, Catalonia's PD expresses its values, ideas, procedures and ethics through mass media and social media (Xifra and McKie, 2012).

New global interconnectivity has led the noopolitik age to be ruled by society rather than by governments and has also empowered the networks of non-states organisations and institutions, which can now sit alongside those of classical states structures. At the same time, it has also empowered the field of public relations, when classed as the establishment of a relationship of knowledge within the new communication channels 
which society is now exposed to in modern times (Xifra and McKie, 2012).

Relationship management is now considered a central practice for public relations (Ledingham, 2003; Fernández-Cavia and Huertas, 2009), as well as for nation branding and public diplomacy. As Szondi (2010) explains, “engaging the domestic as well as the international media in the nation branding initiative is also PR's responsibility, by building strategic relationships among media outlets, journalists and the organisations involved", as creating and maintaining a positive opinion toward a nation is the core task of public diplomacy (Wang, 2006).

Public relations skills, indeed, play an important role not only in place branding as a general discipline (Fernández-Cavia and Huertas, 2014), but specifically in new nationalisms' communication strategies, among which there is a need for "projecting national identity using public diplomacy, soft power and noopolitik tactics in their stateless nation building process" (Xifra, 2009).

Politics in an information age may ultimately be about the nation's stories that win in terms of credibility, although "Information that appears to be propaganda may not only be scorned, but it may also turn out to be counterproductive if it undermines a country's reputation for credibility" (Nye, 2008). As Wang (2006) suggests, from a public relations perspective, "managing national reputation is not just about projecting a certain national image but rather negotiating understanding with foreign publics".

As Guibernau (2014) puts forward, in the Catalan-Spanish conflict, "power is crucial to unlock the situation, but it is not the only factor and less so in a global world". And here is where public diplomacy can play a crucial role.

From the existing literature, it is not clear yet how sub-state entities can set up a successful strategy allowing them to reach global visibility. Public diplomacy has been traditionally linked to countries and governments with political full power. This is not 
the case of Catalonia and its struggle to capture the world's "hearts and minds" in other to convince them about the fairness of its claims for independence.

This is why DIPLOCAT may be considered a relevant case study that demonstrates how regions or non-state nations can endeavour a public diplomacy strategy to successfully gain international attention by the means of academic debate, exchange programmes, media relations and digital engagement.

\section{Aims and method}

The aim of the study is twofold: On the one hand, it analyses how DIPLOCAT works, its organization, structure and goals. On the other hand, the study tracks the current perceptions that international correspondents in Spain have towards Catalonia and explores whether these perceptions have any connection with the professional relationship they have previously established with DIPLOCAT officials. Considering these two different aspects, the study answers the following research questions.

Understanding the relational nature of public diplomacy, Cull's description of the discipline and Catalonia's special situation as a stateless nation:

RQ1: Can DIPLOCAT and the actions the institution carries out be considered as Public Diplomacy?

O RQ1.1: Is the DIPLOCAT consortium structure and organisation appropriate for representing Catalonia abroad in the most truthful way possible?

○ RQ1.2: Are DIPLOCAT's PD strategies successful in achieving influence on foreign public opinion considering the number and accuracy of news that has been published? 
Acknowledging that traditional media are still major players in international communications and the power of journalism in shaping the audience's perception of the world:

RQ2: Do international correspondents in Spain have a good perception of Catalonia?

O RQ2.1: Can this perception be related to the professional relationship correspondents have with DIPLOCAT?

o RQ2.2: Is DIPLOCAT communicating with international correspondents through the channels they mostly use and value?

The first part of this study aims to understand what DIPLOCAT is, who takes part in it and what its nature is. This section of the project consists of a case study that attempts to understand the institution's public diplomacy strategies and its main actions. In order to do that, the main DIPLOCAT officers in each of the fields the institution considers as fundamental as part of its PD strategy have been interviewed (See Table 1).

Table 1. List of interviewed DIPLOCAT Officers

\section{DIPLOCAT Officers responsibilities

Date Identification

- Secretary General

28 April

2015

- Digital Diplomacy Officer

- International Media Officer

- International Debates Officer
22 April

2015

22 April

2015

22 April

2015
I1

I2

I3

I4 
- International Visitors Program (IVP) 22 April

I5

Officer

The second part of this research aims to identify the perceptions that international correspondents from some of the most influential countries in the Western world (Germany, UK, France and USA) have towards Catalonia. In order to do that, a questionnaire was addressed and filled in by all participants (See Table 2).

Table 2. List of contacted journalists

\begin{tabular}{lcc}
\hline Journalist position & Media & Date \\
& country & \\
\hline
\end{tabular}

- The Guardian correspondent

UK $\quad$ May 2015

- Regular contributor to: Daily

UK

May 2015

Telegraph, The Times, The

Independent, Financial Times, Al

Jazeera.

- The Guardian author of "Catalonia

UK

May 2015

Tales"

- Information not authorised to

USA May 2015

publish

- International New York Times

USA

May 2015 correspondent

- Bild Zeintung correspondent

Germany May 2015

- Berliner Zeitung correspondent

Germany May 2015

- Süddeutsche Zeitung correspondent

Germany May 2015

- Les Echos correspondent

France May 2015 
This action was carried out taking into account the importance of journalists in shaping the world's reality, as noted in the literature review section of this study. All contacted correspondents were residing in Spain or had lived in the country temporarily in the recent past, mainly in Madrid and Barcelona, the two major poles of political, media and public relations activity in Spain (Huertas and Fernández-Cavia, 2006) .

The questionnaire was sent electronically and takes into account the potential influence that each individual's personal point of view on the region may have on the public opinion of their respective countries. It attempts to understand whether their perceptions towards the region have changed, whether Catalonia's independence movement might have a connection with these possible changes, and the channels through which they search for or hear information about Catalonia. This part of the research specifically aims to draw conclusions from the possible connections between the public diplomacy activities provided by DIPLOCAT and the professional needs of these professionals (most valuable sources of information, the main media they primarily use when searching for information on the region, etc.).

This study adopts a qualitative approach in order to delve into the experiences and impressions of both DIPLOCAT Officers and international correspondents.

For both interviews and questionnaires, this research employs a type of non-probability sample called an opportunity or convenience sample. The sample population has been selected considering the accessibility and availability of the sources.

The present research draws on the interpretative paradigm. It considers the interaction with the object of study (both DIPLOCAT and international correspondents) as essential in discovering new aspects of interest and comprehension. It employs interviews, systematic observation and a case study as the methods for producing knowledge. It aims to understand rather than scientifically explain the matter of subject. 
The research is based on subjective bases, considering that background knowledge and influences the researchers have been exposed to may influence the research itself and the structure on which it is based.

\section{Findings}

\subsection{DIPLOCAT's Public Diplomacy role}

\subsubsection{DIPLOCAT's collaborative nature between nation branding and PD}

DIPLOCAT has a collaborative nature. The institution is a public-private consortium and, thus, it aims to reach and include in the entity as many collectives, associations, institutions or companies as well as to reach win-win agreements with them. According to DIPLOCAT's Secretary General, the aim of reaching this broad and diverse entities and bodies is "to represent as faithfully as possible all the features and assets that contribute to create the Catalan reality in its day-to-day activity through the practice of public diplomacy" (I1, 2015, personal communication).

According to I1, by taking profit of "all the synergies of these institutions when carrying out activities abroad", DIPLOCAT aims to reinforce both relations between the civil society and the Catalan institutions and relations between the civil society and the institutions abroad. DIPLOCAT's different sources explain that because around $90 \%$ of the body's activity is carried out abroad, it is essential to collaborate closely with institutions that, like DIPLOCAT, have large network-building capabilities.

\subsubsection{DIPLOCAT's triangular PD strategy and actions}

When focusing on the overall public diplomacy's activity carried out by DIPLOCAT in relation to Catalonia's will of self-determination, the consortium is executing a concrete 
and strategic plan in order to be present in the international public opinion. According to DIPLOCAT's Secretary General, the consortium follows a "triangular strategy" which targets the academic sector, foreign press and foreign political parties and parliaments:

a) Academic sector: DIPLOCAT considers that being in touch with the academic field is crucial in order to achieve its objectives. Its sources reveal that some of their main targets are think-tanks, prestigious universities, different field experts and scholars. The aim when establishing contact with them is to let these actors know the Catalan process with the objective of boosting its prestige within academic circles. In this sense, debates carried out both abroad and within Catalonia are a key tool to work on. I4 states, "we are aware of the fact that the academic debates", which DIPLOCAT organises both abroad and within Catalonia, "are the prelude of political debates in a mid-long term. We want papers about the issue to be published" (I4, 2015, personal communication).

I4 continues, "because of our large academic baggage we have built an important relationship with lots of academic institutions", which highlights the huge advantage DIPLOCAT has by possessing all the Catalan universities as members of the consortium.

According to DIPLOCAT's sources, the function of international debates are to define the identity of Catalonia, its political self-determination process and the possibilities and uncertainties facing the debate from different perspectives and patterns. In reference to speaker's plurality, DIPLOCAT's sources argue that they always contact personalities both against and in favour of independence with the aim of creating a balanced academic dialogue on the issue. In accordance to I4, however, that is sometimes difficult, "not because we don't want to, but because some people refuse to participate". 
Regarding the debates organised in Barcelona, they mainly make reference to topics that are of global impact, aiming to "internationalise the Catalan society bringing here the Planet's greatest challenges" says I4.

b) Foreign press: According to I1, in its beginnings, DIPLOCAT's consortium was aware of the difficulties that exporting Catalonia's reality abroad represented due to the fact that most of the information about the region was being spread, "either by international correspondents based in Madrid or international media that used Madridedited newspapers as their main sources of information for understanding the Catalan movement" (I1, 2015, personal communication). To overcome this situation, DIPLOCAT has elaborated strategic activities that consist of the following:

1. To invite foreign journalists to Catalonia in order to personally show them Catalonia's reality and to provide them direct sources from within the region.

DIPLOCAT does this mainly through its International Visitors Programme (IVP). Inspired by similar American initiatives, DIPLOCAT is bringing people from different countries and fields (mainly journalists, politicians and writers) to Catalonia for 48-hour tours to inform them about the region's institutions, its people and its politicians in order to establish bonds of confidence and cooperation. According to DIPLOCAT's International Visitors Programme (IVP) Officer, rather than influencing, the programme is a mutual beneficial action. As stated by I5, "it is impossible to think IVP is based in utilitarianism. We primarily aim to shape a mid to long-term relationship based on shared trust and knowledge" (I5, 2015, personal communication).

According to DIPLOCAT's sources, these visits are the most effective way to inform journalists in particular about the social reality in Catalonia and to achieve the most precise description as possible of the Catalan political process. 
At the same time, they provide visitors with direct sources from within Catalonia, including parties and civil organizations with different ideologies, trade unions, local journalists or scholars, among others.

2. To place opinion articles in international media as a way of explaining Catalans' will of voting and political process. In a two-year period, DIPLOCAT media relations activity has placed around 50 articles in the international media which reference the Catalans' will of self-determination, something DIPLOCAT members spoken to within this study seem to take particular pride in. However it is noted by I1 that, "this success has been accomplished thanks to an attractive political reality that attracts the attention". The process of placing an article, however, is laborious ${ }^{1}$. According to I3, "the date of publication and the publication itself is a conflict of interests and a process of negotiation" that finally consists in establishing a good relationship with the media (I3, 2015, personal communication). DIPLOCAT sources explain, however, it is sometimes difficult to see accurate stories and reports about Catalonia in the media from countries with very different political realities and agendas.

c) Foreign political parties and parliaments: DIPLOCAT's sources confess that foreign political parties and parliaments have been a priority target especially during 2015. The consortium's sources believe that since the general public is better informed and predisposed to understand the Catalan reality, it is time for this issue to be brought into different forums and public debates, both within political parties and entire parliaments. "Our goal is that they are well informed. Then, if they decide to celebrate debates about the issue in plenaries or to present motions, that's really

\footnotetext{
${ }^{1}$ Diplocat has calculated the estimated economic value their placed Op-eds have on international media (Diplocat, 2015).
} 
positive" (I1, 2015, personal communication). ${ }^{2}$

The most common ways in which DIPLOCAT has established such contact have consisted of "taking actions such as public and private meetings, bilateral meetings and conferences" (I1). The institution has also addressed foreign committees from different parliaments, carried out conferences for their members, as well as holding meetings with different European political parties.

\subsubsection{Digital Diplomacy}

DIPLOCAT favours Twitter as its main social media channel due to its high use among journalists, diplomats, politicians, opinion makers and political group advisors. According to DIPLOCAT's Digital Diplomacy Officer, “Twitter allows you to directly knock on the door of global personalities. Maybe he or she won't see the message personally, but his or her communication team will" (I2, 2015, personal communication).

One of DIPLOCAT's main Twitter accounts is @ CatalanVoices, a profile based on the "Rotation Curation" concept invented by the @Sweeden Twitter account. As states I2, its aim is "to present current people that create debate and interactions through their day-to-day activities and life experiences in English". It consists of an account run by different people who are usually not in the public eye every week (the curators).

The other main profile is @ ThIsCatalonia, which is DIPLOCAT's official PD account for foreign audiences and the main channel using foreign languages. Following the pattern set by other public diplomacy Twitter profiles such as @ ThisisFinland or @ThisisChile, the account aims to broadcast all the government-related or third-party

\footnotetext{
${ }^{2}$ The clearest achievement in relation to this matter for Diplocat occurred in the Danish Parliament on May 12, 2015. The Danish chamber requested a dialogued, democratic and pacific solution between Catalonia and Spain (La Vanguardia, 19 May 2015).
} 
news in different fields published mainly in English or other languages. According to I2, this profile in particular uses small countries such as Sweden, Lithuania or Finland as a set example to follow as they, "are developing a great task in PD and digital Soft Power".

Finally, consortium's sources explain that DIPLOCAT's main project is the website Catalonia Votes (www.cataloniavotes.eu). The relevance of this web-portal lies in the information about the Catalan political process explained in foreign languages. According to DIPLOCAT's International Press Officer, due to the lack of Catalan media providing information in foreign languages, DIPLOCAT considered it essential practice to create Catalonia Votes in order to convey three basic points: "that there is a social majority in favour of voting, how it is aimed to be done by the Catalan institutions and which actors (and arguments) are in favour and against it” (I3, 2015, personal communication).

\subsection{International correspondents' perceptions towards Catalonia}

Some of the publics that DIPLOCAT's PD has strategically targeted as essential are foreign correspondents established in Spain. As we have seen when analysing DIPLOCAT, one of the institution's objectives through the IVP is to facilitate a preferred narrative of Catalonia and to provide correspondents with direct sources from the region. Moreover, DIPLOCAT's different experts have made clear that the momentum of the Catalan political process has generated great interest among the main global media channels. Finally, consortium sources have also pointed at the differences in terms of sympathy that this process generates among media and the public opinion from different countries. 
This section of the article tries to deepen and qualitatively check the accuracy of such statements by analysing the questionnaire responses of 9 different international correspondents who are currently established or who have lived in Spain for a certain period of time ${ }^{3}$. Hereafter, some of the main results are highlighted.

As the questionnaire responses reveal, correspondents have a unanimous positive opinion about Catalonia, with no participants stating any negative perceptions towards the region. The two journalists responding N/A can be classed as not having a positive nor a negative perception of Catalonia, but rather they have either a more complete perception or do not want to position themselves.

Although all correspondents employ different concepts when being asked to describe Catalonia in three words, we can appreciate at least four main aspects the majority of participants identified with when thinking about the region: the city of Barcelona; football (especially FC Barcelona); the independence movement; and the internationally known Gaudí architect. On the other hand, most correspondents refuse to describe Catalan people in three words, considering it is not fair to tag people in such a simple way.

All correspondents unanimously agree that today they hear more about Catalonia than a few years ago. However, when asked about whether their opinion on the region has changed over the last few years, the same number of participants (4) chose yes and no. Most correspondents admit that the Catalan political situation is an issue they usually make use of in their reports (seven out of nine) and, in a parallel way, they agree that this issue creates significant interest in the countries their media channels operate in (seven out of nine). It is relevant to look at the difference in opinions among journalists working for the media from different countries when asked about the reasons behind

\footnotetext{
3 All the questionnaires graphics are available from the authors.
} 
such interest. The fact that all British media correspondents believe this interest comes from the similarities between the Scottish and the Catalan political situations needs to be highlighted. Some of the other reasons that were mentioned are connected to football, tourism or economy.

When looking at the channels through which journalists usually hear more about Catalonia, traditional mass media plays an important role, being the channels through which respondents hear more about the region.

Likewise, internet media channels are also a remarkably important source for these correspondents when they look for information related to Catalonia, even though personal contacts remain as the most important sources for these professionals (Figure $1)$.

\section{Figure 1. International correspondents most used sources when}

\section{looking for information about Catalonia}

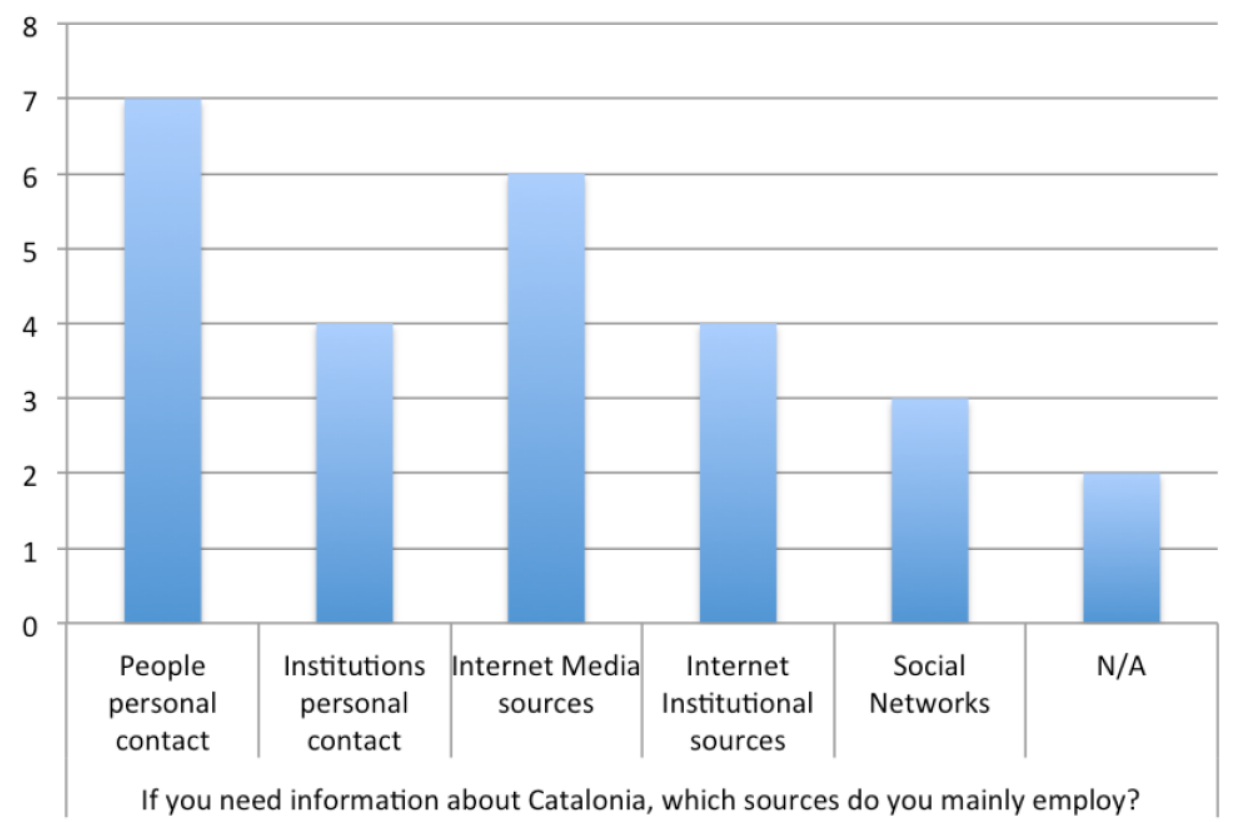

Source: research from the authors 
It must also be mentioned that all correspondents know what DIPLOCAT is and that the majority of them have established contact with the institution at some point (seven out of nine). The main reasons that explain this direct and indirect contact are, for example, correspondents' visits to Catalonia during events like Sant Jordi 'Books \& Roses Day' or the non-binding Vote of Independence on November $9^{\text {th }} 2014$. Participants had also gained awareness of DIPLOCAT through press releases and information that the consortium had sent to correspondents through email.

As a final statement, the findings in the questionnaires indicate that the correspondents' personal sources are key when they need to look for information relating to Catalonia. This clearly legitimates DIPLOCAT's attempts to provide these correspondents with direct sources from the region through the institution's International Visitors Programme. Similarly, projects such as the one dedicated to the website "Catalonia Votes" may also be effective considering the correspondents' recurrent use of internet media sources.

\section{Discussion}

The strategies regarding Catalonia's self-determinism and the will to hold a referendum carried out by DIPLOCAT's PD are addressed at the establishment of contact with general internet and social media users, journalists, international politicians and influencers. Compared to Cull's PD components taxonomy, DIPLOCAT focuses mainly in three of them: advocacy, exchange and international broadcasting, but changing in the last case international television networks by social media use, due tu the lack of resources.

Following Malone's (1985) line of argument when describing the PD' objectives, DIPLOCAT is working to affect foreign countries' public opinion in order to impact 
foreign political decisions as well. It especially focuses on the European area and institutions, where the Catalan political process could play a key role in the future.

Here, the concept of soft power described by Nye (2004) becomes crucial in DIPLOCAT's strategy. The institution uses Catalonia's attractiveness in terms of values, culture and policies in order to project the region's reality.

DIPLOCAT, as a consortium, also tries to reach this aim by integrating the most significant institutions and entities from the territory, while it also attempts to create synergies by working together with them. By doing so, DIPLOCAT aims to be identified as a credible body when representing Catalonia internationally, as "source credibility" is a fundamental asset for public diplomacy (Wang, 2006). Building on this, such commitment for uniting the most important actors of the region is in line with the idea pointed out by Quelch and Jocz (2004), who expressed that small states (in this case a region) may have an advantage when spreading a coherent image of a country abroad because of their stakeholders' proximity.

Following Nye's line of argument (2008), the relationship based on the reliability between foreign and Catalan actors (international correspondents and the Catalan society) that DIPLOCAT aims to achieve through personal and digital activities could have significantly positive consequences. All these activities are aligned with what Szondi (2010) considers a "co-creational approach", a public relations strategy applied to nation branding, searching for a co-creation of meaning through "mutually beneficial relations hips" (Heath and Coombs, 2006).

Besides, the Catalan majority opinion being in favour of holding an independence referendum could result in the vote gaining credibility and the movement gaining a positive reputation: two concepts that this study has shown to be fundamental in PD. This development could also be occurring within a wider European framework. 
DIPLOCAT's PD seeks to pool efforts together with the European Union in order to spread a coherent image of the EU, as highlighted by Duke (2013), as well as promote the common soft power values to both Catalans and Europeans (such as, "democracy" or "Europeanization").

The concepts of "paradiplomacy" and "noopolitik age" described by Xifra and McKie (2012) also have a lot to do with DIPLOCAT's PD strategy. This study demonstrates the communication methods that the consortium has been able to put into practice due to the use of the new "noosphere" possibilities (in this case, internet tools). Websites and other social media channels have provided the consortium and the institutions it represents with the ability to interact with other territories at levels shared with other powerful bodies. By doing so, DIPLOCAT is contributing to empowering non-states entities and bodies that make up the Catalan reality. Using the new Internet tools, DIPLOCAT has given the leading role not only to different and plural institutions that represent the territory but also to ordinary citizens, something we can see in the “rotation curation" concept DIPLOCAT uses in its @ThIsCatalonia Twitter account.

Finally, as this project has shown, visibility but especially comprehension and positive impact on media are what DIPLOCAT aims to achieve. Relating to conclusions made by McCombs and Reynolds, (2002) and Anchetti (2011), DIPLOCAT especially takes into consideration the influence that journalists have when shaping the region's image abroad.

DIPLOCAT's sources feel satisfied with the qualitative improvement in the information that correspondents spread nowadays, in comparison to the quality of information being shared in the recent past. Therefore, results obtained from international correspondents' answers indicate that the soft power values and reputation DIPLOCAT is committed to spreading may start to be transmitted from international media channels to foreign 
audiences through these correspondents' picture of the world (McCombs and Reynolds, 2002). Results also show that DIPLOCAT's efforts to show not only positive views about Catalonia's will of self-determination but also critical ones, may be providing the institution with the necessary credibility when developing public diplomacy (Wang, 2006; Nye, 2008; Mor, 2012).

\section{Conclusions}

DIPLOCAT's aim as a Catalan public diplomacy institution is to create international debate about Catalonia's will of self-determination. DIPLOCAT bases its day-to-day activities on reaching collaboration agreements with a broad diversity of Catalan institutions in order to self-reinforce different parts and represent the region as faithfully as possible abroad.

When analysing DIPLOCAT's general PD practice, the consortium can be seen to follow a triangular strategy. DIPLOCAT focuses on three main targets that the consortium considers essential in order to achieve its main goals: the academic sector, foreign press and foreign political parties and parliaments.

These stakeholders have been reached through the practice of a series of strategic activities:

- international debates aimed at internationalising the Catalan will of voting, merely among academic circles;

- an International Visitors Programme aimed at bringing influential people to Catalonia in order to show them its reality as accurately as possible;

- media relations being used to place opinion articles within influential media outlets, and to encourage journalists to write as precisely as possible and providing them with direct Catalan sources 
- Digital Diplomacy employed to spread positive content regarding Catalonia and to stimulate conversation between Catalan and foreign stakeholders.

Finally, this research has investigated the perceptions that international correspondents in Spain have towards Catalonia, which are undoubtedly positive. These perceptions coincide with the fact that almost all correspondents have established contact with DIPLOCAT. A majority also indicate that the sources they use the most when searching for information about Catalonia are the ones DIPLOCAT is committed to providing, such as Catalonia's personal and direct sources through its IVP or digital sources (in foreign languages) like the "Catalonia Votes" webpage. These facts are key, taking into account that they demonstrate that correspondents' interests are in line with what DIPLOCAT is strategically offering.

Catalonia's development of PD and its certain achievements through the use of this practice so far prove that the new global communication order between territories has overcome the old one defined by the nation states' central structures. This research demonstrates that, within the new internet and information age, a small PD structure such as DIPLOCAT can achieve remarkable profits in terms of reputation gaining for the territory it represents if the right tools and strategies are used. What is also unquestionable are the political and social contexts in Catalonia which the consortium has taken advantage of to achieve a greater impact internationally.

Analysis within this study makes clear that relations based on trust, reliability and confidence are essential for the practice of public diplomacy. At the same time, the importance of mutual benefits when establishing relations has proven to be crucial, indeed showing connections between PD and PR practices.

Considering the fact that PD institutions, such as DIPLOCAT, have been only scarcely analysed, this research can add valuable insight to the field. Furthermore, the 
independence movement in Catalonia gives to it an additional interest, considering the yet unknown repercussions of the region's developing political process.

For further research, one question that remains unclear is the issue of how to evaluate PD's real scope and impact. However DIPLOCAT has provided and highlighted some techniques it has developed in order to resolve this problem such as Twitter analytics or the estimated economic value of the articles it has placed within international media, today's methods can certainly be considered as insufficient. Moreover, because of the similarities observed in this study between the fields of public diplomacy and public relations it would be very interesting to further explore the professional implications of their respective academic definitions and scopes. Finally, it would also be necessary to develop further studies focusing on some of the main activities DIPLOCAT carries out, especially considering its International Visitors Programme and Digital Diplomacy activity on Twitter. In these cases, either an observational research or a data content analysis could positively add additional knowledge to the issues under investigation.

\section{References}

Archetti, C. (2011) Reporting the nation: Understanding the role of foreign correspondents in 21st century public diplomacy. International Studies Association (ISA) Annual Convention. Montreal, 16-19 March 2011. .

Anholt, S. (2007) Competitive identity. the new brand management for nations, cities and regions. Hampshire: Palgrave Macmillan.

Badia, F. (Ed.). (2010) Governs subestatals en l'acció exterior. Utopia i realitat a Catalunya. Barcelona: CIDOB edicions.

Castells, M. (2008) The new public sphere: Global civil society, communication networks, and global governance. The ANNALS of the American Academy of Political and Social Science, 616 (1): 78-93.

Catalan Voices. (2015). Retrieved from http://catalanvoices.com/ 
Catalan public diplomacy data (2015). Diplocat. Diplocat. public diplomacy council of Catalonia. Retrieved from http://diplocat.cat/en/

Cull, N. J. (2018) Public diplomacy: Taxonomies and Histories. The ANNALS of the American Academy of Political and Social Science, 616: 31-54.

Cull, N. J. (2010) Public diplomacy: Seven lessons for its future from its past. Place Branding and Public Diplomacy, 6 (1): 11-17.

Duke, S. (2013) The European external action service and public diplomacy. Discussion Papers in Diplomacy, 127. The Hague: Netherlands Institute of International Relations 'Clingendael'.

Economic value op-eds and articles. (2015). Diplocat.

Fernández-Cavia, J. and Huertas, A. (2009) Redacción en relaciones públicas. Madrid: Pearson Prentice Hall.

Fernández-Cavia, J. and Huertas, A. (2014) La gestión de las marcas de destino y de territorio desde la perspectiva de las relaciones públicas. Comunicació. Revista de recerca i anàlisi, 31 (1): 9-26.

Gilboa, E. (2008) Searching for a theory of public diplomacy. The ANNALS of the American Academy of Political and Social Science, 616 (1): 55-77.

Gilboa, E. (2005) The CNN effect: The search for a communication theory of international relations. Political Communication, 22 (1): 27-44.

Guibernau, M. (2014) Prospects for an independent Catalonia. International Journal of Politics, Culture and Society, 27: 5-23.

Hayden, C. (2013) Engaging technologies: A comparative study of U.S. and Venezuelan strategies of influence and public diplomacy. International Journal of Communication, 7: 1-25.

Heath, R. and Coombs, W.T. (2006) Today's Public Relations: An Introduction. Thousand Oaks, California: Sage.

Huertas, A. and Fernández-Cavia, J. (2006) Centre and Periphery: Two speeds for the implementation of public relations in Spain. Public Relations Review, 32: 110-117.

Keating, M. (1996) Nations against the state: the new politics of nationalism in Quebec, Catalonia and Scotland. New York: Springer.

LaVanguardia.com (2015) El parlamento danés apuesta por el "diálogo pacífico y democrático" para resolver la cuestión catalana. March, 19th.

Ledingham, J.A. (2003) Explicating Relationship Management as a General Theory of Public Relations. Journal of Public Relations Research, 15 (2): 181-198. 
Malone, G. (1985) Managing public diplomacy. Washington Quarterly, 8 (3): 199-213.

McCombs, M. and Reynolds, A. (2012) How the news shapes our civic agenda. In: J. Bryant, and M. B. Oliver (Eds.) Media effects: Advances in theory and research, New York: Routledge.

Mor, B. D. (2012) Credibility talk in public diplomacy. Review of International Studies, 38 (2): 393-422.

Nye, J. (2004) Soft power: The means to success in world politics. New York: Perseus Books Group.

Nye, J. (2008) Public diplomacy and soft power. The ANNALS of the American Academy of Political and Social Science, 616 (1): 94-109.

Quelch, J., and Jocz, K. (2005) Positioning the nation-state. Place Branding, 1 (3): 229237.

San Eugenio, J. and Xifra, J. (2015) International representation strategies for stateless nations: The case of Catalonia's cultural diplomacy. Place Branding and Public Diplomacy, 11 (1), pp. 83-96.

San Eugenio, J., Ginesta, X. and Xifra, J. (2017) Catalonia's public diplomacy and media relations strategy: A case study of the Eugeni Xammar Programme of International Communication and Public Relations. In: I. Somerville, O. Hargie, M. Taylor and M. Toledano (eds.) International Public Relations. Perspectives from deeply divided societies, pp. 113-130.

Szondi, G. (2008) Public diplomacy and nation branding: Conceptual similarities and differences. The Hague: Netherlands Institute of International Relations 'Clingendael'.

Szondi, G. (2010) From image management to relationship building: A public relations approach to nation branding. Place Branding and Public Diplomacy, 6: 333-343.

Wang, J. (2006) Managing national reputation and international relations in the global era: Public diplomacy revisited. Public Relations Review, 32 (2): 91-96.

Xifra, J. (2009) Catalan public diplomacy, soft power, and noopolitik: A public relations approach to Catalonia's governance. Catalan Journal of Communication \& Cultural Studies, 1, 67-85.

Xifra, J., and McKie, D. (2012) From realpolitik to noopolitik: The public relations of (stateless) nations in an information age. Public Relations Review, 38 (5): 819-824. 